\title{
Reciprocal Influence of Performance, Organizational Commitment and Work Satisfaction Private Universities' Lecturer' in East Java
}

\author{
Fathorrahman \\ Management Program, Sekolah Tinggi Ilmu Ekonomi ASIA Malang, Jalan Borobudur 21 Malang, \\ Jawa timur, Indonesia
}

\begin{abstract}
The quality determinant components in universities consist of many components, lecturers become something that is very important in an effort to improve the quality of universities. Many views claim that the quality of education can be achieved through improving the lecturers' quality. Organizational commitment, work satisfaction and lecturers' performance are important topics to be studied in order to improve the lecturers' quality. This study is a causality study, sampling technique used stratified random sampling with the number of samples were 85 lecturers and the number of lecturers who return the complete questionnaire was as many as 63 respondents. The result of hypothesis test in this study were 1). Organizational commitment has no significant effect on lecturer's performance; 2). Performance has no significant effect on organizational commitment of lecturers; 3). Organizational commitment has a significant effect on lecturers' work satisfaction; 4). Work satisfaction has a significant effect on organizational commitment of lecturers; 5). Performance has a significant effect on the lecturers' job satisfaction; and 6). Job satisfaction has a significant effect on lecturers' performance.
\end{abstract}

Keywords: organizational commitment, performance, work satisfaction

DOI: $10.7176 / \mathrm{EJBM} / 11-26-09$

Publication date:September $30^{\text {th }} 2019$

\section{INTRODUCTION}

The government's strategic plan in the field of higher education in the current globalization era is to improve universities to be an advanced and qualified universities. Universities are constantly charged to be innovative, qualified, and responsive to the global developments and local challenges, their success depends on the growth and the effort to grow. The main drivers of the growth are the universities' lecturers (Hendrajaya, 1999: 17).

The demands of society on the quality of universities as a result of globalization is something natural, the solution cannot be delayed any more. This means that the learning process in university must be qualified and meet the established quality standards. The existence and challenges of universities are highly dependent on stakeholders' assessment on the quality of the universities.

The quality determinants components in universities consist of many components, including the quality of academic programs (ranging from input, learning process, and graduate output), human resources, facilities and infrastructure and academic atmosphere. From all of the components, the human resource factor, that is a lecturer become something which is very important in an effort to improve the quality of the university. Because of the important role of lecturers in universities, the attention to the performance and work satisfaction of lecturers in carrying out their profession is very important and need to be considered.

Lecturers in universities play a strategic role in academic and student affairs. Many views claim that the quality of education can be achieved through improving the lecturers' quality. It is because the lecturers serve as an agent that transforms knowledge to the students, so if the lecturers are qualified, it is expected that knowledge transformed is also qualified which in turn can improve the quality of students and universities' graduation. This is proved from the findings of previous research that in education is applying "the man behind the system", human is a key factor that determines the power of education (Miller, 1980; 76). In fact, education as a service industry is "front line provider and determine the quality of service delivery system", lecturers are at the forefront in determining the quality of service (Sallis, 2002: 35).

\section{LITERATURE REVIEW AND HYPOTHESIS}

The Relation between Organizational Commitment and Performance

According to Cichy (2009) organizational commitment can be explained through two points of view. First, describing the individual's desire or preference to keep working in the old organization. Both indicate an individual's attitude towards the organization and are reflected in the individual's relationship with the company. So, with a high organizational commitment, then the individual will strive by using all the abilities to improve its performance that will ultimately improve the company's performance. Organizational commitment is defined as the employee's attachment to the organization in which the employee works. There are three components of organizational commitment, namely affective commitment, continuity commitment and normative commitment 
(Allen \& Meyer, 1990; Meyer \& Allen, 1997).

Related to employee performance, it shows that if employees have high commitment they will be able to improve their performance which in turn can improve organizational performance. This is in line to a research by DeCotiis and Summers (1987) who found that organizational commitment is a strong predictor on employee's performance as well as a research by Jaramillo et al., (2005) which found that organizational commitment and performance have a positive relationship to the sales and non-sales employees. The same results are also shown by the results of a research by Chen and Francesco (2003) and Sudiro (2008). Meanwhile, Yiing and Zaman (2009) found that commitment has no effect on employee performance. While the study of Both Steers (1977) and Wiener and Vardi (1980) yields the conclusion that organizational commitment has an unclear relationship with performance. From several research results above, the researcher develops the first hypothesis as follows:

H1a: Organizational commitment has a positive effect on lecturers' performance.

H1b: Performance has a positive effect on lecturers' organizational commitment of lecturers.

The Relation Between Organizational Commitment and Work Satisfaction

Commitment is known as the intention of employees to continue working within the organization (Meyer, 1997). This means that for employees who have a high organizational commitment to the organization then he will feel better job satisfaction, otherwise then he will feel less work satisfaction.

The results of a study from Lee and Mowday (1987) mentioned that work satisfaction and organizational commitment are interrelated. The linkage of organizational commitment to work satisfaction, indicating that organizational commitment can affect contradictory to the job satisfaction. That is, if employees feel satisfied in their work, then they will have a high commitment to the organization. Whereas when employees are not satisfied in the workplace, they are less committed and will seek other opportunities to quit. Conversely, employees who have a high commitment to the organization then they can increase the work satisfaction. The same is also shown by the results of the study by Sudiro (2008) and Westover et al., (2010).

Research conducted by Gunz and Gunz (1994), Knoop (1995) and Young et al. (1998) found that there was a relationship between work satisfaction and organizational commitment. These results were in line with Martin \& O'Loughlin's (1984) study, demonstrating that job satisfaction at a US army consistently influences an increase in organizational commitment, as well as research by Carmeli et al. (2004) who found that work satisfaction has an influence on work commitment and work performance.

This result is in line with Lok and Crawford's research. (2001), which examines the antecedents of organizational commitment and the mediating role of work satisfaction. The study was conducted in 32 hospitals in Australia with a final total of 251 employees and hospital doctors. The results showed that work satisfaction had a positive influence on organizational commitment significantly. While Gorda (2002) discussed the influence of manager quality, work satisfaction, and corporate culture to the commitment and performance of hotel managers in Bali. The tool used is path analysis to 70 respondents in the form of hotel managers who have worked at least five years, using variable of quality manager, work satisfaction, and corporate culture as exogenous variable and individual manager performance as endogen variable. The results of his research found that work satisfaction (only intrinsic satisfaction) that significantly influence the commitment of managers. However, the above results differ from those of Yiing and Zaman (2009) finding out that organizational commitment had a significant negative effect on work satisfaction.

From some controversy result of research above, hence researcher develop second hypothesis, as follows:

H2a: Organizational commitment has a positive effect on lecturers' work satisfaction. H2b: Work satisfaction has a positive effect on lecturers' organizational commitment.

\section{The Relation Between Performance and Work Satisfaction}

The study of the relationship between work satisfaction and performance is one of the most important studies in industrial-organizational psychology. From several related studies on the relationship between work satisfaction and performance, it showed that there had always been a controversial opinion about the relationship between work satisfaction and employee performance and it always becomes an interesting topic, some argued that satisfaction affected the performance, some others argued on the contrary that is precisely the performance that affects work satisfaction (Judge et al., 2001).

Work satisfaction is an effectiveness or an emotional response to various aspects of work. A person can be relatively satisfied with an aspect of his job and dissatisfied with one or more of the other aspects. This study shows that work satisfaction presents a psychological condition for pleasure or displeasure depending on the fulfilled or unfulfilled desired needs and appropriate or inappropriate need between expected and the real value obtained.

Work satisfaction is caused by performance or work achievement so that more productive workers will get satisfaction. Karatepe and Tekinkus (2006) examined the effect of work-family conflicts, emotional fatigue, intrinsic- motivation on the performance of front office employees. This research was conducted by front office employees (FO) of a bank in Turkey. From the total of 450 distributed quizzes, 363 returned quizzes. Analyzer 
used to process the data was using SEM. The results showed that the performance had a significant positive effect on work satisfaction of front office employees. While Zimmerman and Darnold (2009) which stated that employees' performance will lead to work satisfaction. The results support the research of Lawler and Porter (1967); Siegel and Bowen (1971); And Stumpf and Hartman (1984).

However, in another study of the relationship of performance and work satisfaction, it is often assumed that employees who get work satisfaction will carry out their work better. In many cases, there is often a positive relationship between high satisfaction with work performance or high performance, but not always strong enough and significant. There are many employees with high job satisfaction were not being employees whose performance was also high but still only as an average employee. Work satisfaction itself, is not a powerful motivator. The main problem of this relationship is whether work satisfaction leads to better implementation of work or vice versa, work performance leads to work satisfaction. Many studies found an unclear relationship between work satisfaction and work achievement (performance).

Hochwarter et al. (1999) stated that a positive relationship between work satisfaction and performance will occur when the value attainment and the positive effect were high. He pointed to a number of samples where the value of achievement and satisfaction may be high, but performance is not directly affected.

Sudiro (2008) stated that there was a reciprocal relationship between performance and work satisfaction; on one side; work satisfaction leads to improve performance so that satisfied workers will be more productive. The results support the research of (Clark \& Chen, 2018)Chen et al. (2006); Lee et al. (1999); Melamed et al. (1995); Sekoran and Jauch (1978); Dickter et al. (1996); (Sarmiento, Beale, \& Knowles, 2007) that work satisfaction affects performance, in this case satisfied workers were productive workers.

The above results were also in line with Sarmiento, et al. (2007) who examined about the determinants of employees' performance in electronic component manufacturing company in north Mexico in 1999. This research seeks to determine the factors that affect employees' performance. The results showed that work satisfaction had a significant positive relationship to performance, age was not related to performance, and education was not related to performance. From the opinions, it can be concluded that work satisfaction had a close relationship with employees' performance, the more employees were satisfied the higher the performance.

From some controversy results of research above, hence researcher develop third hypothesis as follows:

H3a: Performance positively affects the lecturer's work satisfaction.

H3b: Work satisfaction has a positive effect on lecturer's performance.

\section{RESEARCH METHOD}

This research was conducted on lecturers in two private religious universities that have an accreditation rating " $A$ " in Surabaya and Malang. The sampling technique was stratified random sampling with the total sample is 63 . The data of this research was obtained through a questionnaire dispersion procedure. From 95 questionnaires distributed, the number of respondents who returned the questionnaires were 63. The results of validity and reliability test of all items in this research variable was valid and reliable. Data that has been valid and reliable was tested by using multiple linear regression test and Path Analysis.

\section{FINDING RESULT}

\subsection{The Result of Multiple Linear Regression Testing}

The first multiple linear regression test was conducted to examine the effect of organizational commitment on lecturers' performance.

Table 4.1.a

The Result of Multiple Linear Regression Testing Coefficients $^{\mathbf{a}}$

\begin{tabular}{|c|c|c|c|c|c|}
\hline \multirow[t]{2}{*}{ Model } & \multicolumn{2}{|c|}{ Unstandardized Coefficients } & \multirow{2}{*}{$\frac{\text { Standardized Coefficients }}{\text { Beta }}$} & \multirow[b]{2}{*}{$\mathrm{t}$} & \multirow[b]{2}{*}{ Sig. } \\
\hline & B & Std. Error & & & \\
\hline (Constant) & 1.677 & .265 & & 6.324 & .000 \\
\hline Work Satisfaction & .298 & .078 & .5 & 3.816 & .000 \\
\hline Organizational commitment & .033 & .072 & .06 & .452 & .653 \\
\hline
\end{tabular}

a. Dependent Variable: Performance

Based on table 4.1.a above, work satisfaction variable has a t value of 3.816 which is greater than the value of $\mathrm{t}$ table at $\mathrm{df}=63$ and $\alpha=0.05$ of 1670 , with sig $\mathrm{t} 0.000<0.05$. The above results show that work satisfaction has a significant effect on lecturers' performance. While the organizational commitment variable has a t value of .452 which is smaller than the value of $t$ table at $\mathrm{df}=63$ and $\alpha=0.05$ of 1670 , with sig $t 0.000>0.05$. The above results show that organizational commitment has no significant effect on lecturers' performance. 
Tabel 4.1.b

The Result of Multiple Linear Regression Testing Coefficients ${ }^{\mathrm{a}}$

\begin{tabular}{|c|c|c|c|c|c|}
\hline \multirow[t]{2}{*}{ Model } & \multicolumn{2}{|c|}{ Unstandardized Coefficients } & \multirow{2}{*}{$\begin{array}{c}\begin{array}{c}\text { Standardized } \\
\text { Coefficients }\end{array} \\
\text { Beta }\end{array}$} & \multirow[b]{2}{*}{$\mathrm{t}$} & \multirow[b]{2}{*}{ Sig. } \\
\hline & $\mathrm{B}$ & Std. Error & & & \\
\hline 1 (Constant) & .705 & .499 & & 1.412 & .163 \\
\hline Organizational commitment & .421 & .092 & .455 & 4.554 & .000 \\
\hline Performance & .655 & .172 & .382 & 3.816 & .000 \\
\hline
\end{tabular}

a. Dependent Variable: Work Satisfaction

Based on table 4.1.b above, organizational commitment variable has t value which is equal to 4,554 and bigger than $\mathrm{t}$ table value at $\mathrm{df}=63$ and $\alpha=0,05$ equal to 1,670 , with sig $\mathrm{t} 0.000<0.05$. The above results show that the performance has a significant effect on the work satisfaction of lecturers. While the performance variable has a $t$ value of 3.816 which is greater than the value of $t$ table at $\mathrm{df}=63$ and $\alpha=0.05$ of 1670 , with sig $t 0.000$ $<0.05$. The above results show that the performance has a significant effect on the work satisfaction of lecturers.

Tabel 4.1.c

The Result of Multiple Linear Regression Testing Coefficients ${ }^{\mathbf{a}}$

\begin{tabular}{|c|c|c|c|c|c|}
\hline \multirow[t]{2}{*}{ Model } & \multicolumn{2}{|c|}{ Unstandardized Coefficients } & $\begin{array}{l}\text { Standardized } \\
\text { Coefficients }\end{array}$ & \multirow[b]{2}{*}{$\mathrm{t}$} & \multirow[b]{2}{*}{ Sig. } \\
\hline & $\mathrm{B}$ & Std. Error & Beta & & \\
\hline (Constant) & .569 & .606 & & .938 & .352 \\
\hline Performance & .104 & .230 & .056 & .452 & .653 \\
\hline Work Satisfaction & .610 & .134 & .564 & 4.554 & .000 \\
\hline
\end{tabular}

a. Dependent Variable: Organizational Commitment

Based on table 4.1.c above, the performance variable has a t value of .452 which is smaller than the value of $\mathrm{t}$ table at $\mathrm{df}=63$ and $\alpha=0.05$ of 1670 , with sig t $0.000>0.05$. The above results show that the performance does not significantly affect the organizational commitment of the lecturers. While work satisfaction variable has t value which is equal to 4,554 and bigger than $\mathrm{t}$ table value at $\mathrm{df}=63$ and $\alpha=0,05$ is equal to 1,670 , with sig t 0.000 $<0.05$. The above results show that work satisfaction has a significant effect on organizational commitment of lecturers.

From the results of multiple linear regression testing, the researchers can describe the path relationships between variables as shown in Figure 4.1 below:

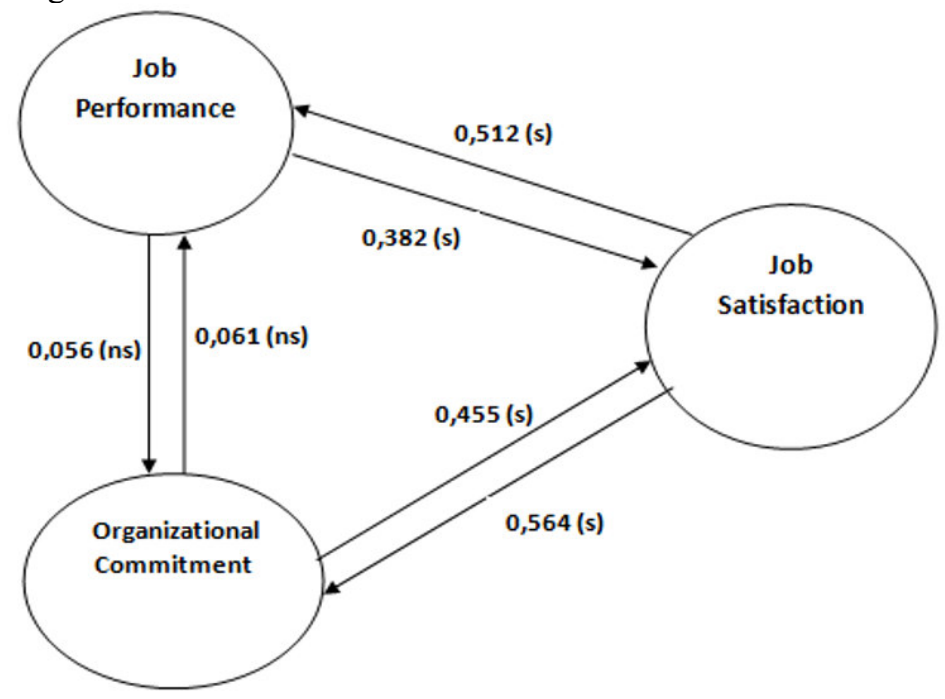

Figure 4.1

Modelling Result 


\subsection{Hypothesis Testing}

There are six hypotheses in this study. The following are the results of tests on all six hypotheses.

H1a: Organizational commitment affects the performance

H1b: Performance affects the Organizational commitment

The path coefficient 0.061 ( $\mathrm{Sig}=0.653$ ) from organizational commitment to lecturers' performance is not significant with positive direction. The above results show that organizational commitment has no significant effect on lecturers' performance, so $\mathrm{H} 1 \mathrm{a}$ is rejected. Path coefficient 0,056 ( $\mathrm{Sig}=0,653)$ from performance to organizational commitment of lecturers is not significant with positive direction. The above results show that the performance has no significant effect on organizational commitment of lecturers, so $\mathrm{H} 1 \mathrm{~b}$ is rejected.

H2a: Organizational commitment has a positive effect on lecturers' work satisfaction.

H2b: Work satisfaction has a positive effect on lecturers' organizational commitment.

The path coefficient 0,455 ( $\mathrm{Sig}=0,000)$ from organizational commitment to lecturers' work satisfaction is significant with positive direction. The above results show that organizational commitment has a significant effect on the work satisfaction of lecturers, so that H2a is accepted. Path coefficient of 0,564 ( $\mathrm{Sig}=0,000)$ from work satisfaction to organizational commitment of lecturers is significant with positive direction. The above results show that job satisfaction has a significant effect on organizational commitment of lecturers, so that $\mathrm{H} 2 \mathrm{~b}$ is accepted.

H3a: Performance positively affects the lecturers' work satisfaction.

H3b: Work satisfaction has a positive effect on lecturers' performance.

The path coefficient 0.382 ( $\mathrm{Sig}=0,000$ ) from the performance of the lecturers to the work satisfaction is significant with the positive direction. The above results show that the performance significantly affects the work satisfaction of lecturers, so that $\mathrm{H} 3 \mathrm{a}$ is accepted. Path coefficient of 0,512 ( $\mathrm{Sig}=0,000)$ from work satisfaction to lecturers' performance is significant with positive direction. The above results show that work satisfaction has a significant effect on lecturers' performance, so H3b is accepted.

\section{DISCUSSION}

\subsection{The Discussion of the Result of the Study}

From the result of the hypothesis testing above, the researcher will discuss the effect of the variables in this study as follows:

\subsubsection{The Effect of organizational Commitment to Performance and the Vice Versa}

From result of hypothesis 1a testing, path coefficient 0.061 ( $\mathrm{Sig}=0.653)$ from organizational commitment to lecturers' performance is not significant with positive direction. The above results show that organizational commitment has no significant effect on lecturers' performance. Means that hypothesis 1a, which states organizational commitment has a positive effect on the performance of lecturers, is not proven. Path coefficients are marked positive, theoretically it means that the influence of organizational commitment to performance is in the same direction.

The results of this study are in line with Mathieu and Zajac's (1990); And Yiing and Zaman (2009) which states that organizational commitment has no direct effect on performance. However, the results of this study are different from Darwito's (2008), Burton (2002), Jaramillo, et. al (2005), and Sudiro's (2008) study's results indicate that organizational commitment has a positive effect on employees' performance.

From result of hypothesis testing $1 \mathrm{~b}$, path coefficient $0,056(\mathrm{Sig}=0,653)$ from performance to organizational commitment of lecturers is not significant with positive direction. The above results show that the performance does not significantly affect the organizational commitment of the lecturers. It means that hypothesis $1 \mathrm{~b}$, which states the performance has a positive effect on organizational commitment of lecturers, is not proven. Path coefficients are marked positive, theoretically it means that the effect of performance on organizational commitment is in the same direction.

The results of this study are in line with research from Both Steers (1977) and Wiener and Vardi (1980) which concluded that organizational commitment has an unclear relationship with the performance.

\subsubsection{The Effect of Organizational Commitment to Work Satisfaction and the Vice Versa}

From the result of hypothesis 2 a testing, path coefficient $0.455(\mathrm{Sig}=0.000)$ from organizational commitment to work satisfaction of lecturers is significant with positive direction. The above results show that organizational commitment has a significant effect on work satisfaction of lecturers. It means that hypothesis $2 \mathrm{a}$, which states organizational commitment has a positive effect on the lecturers' work satisfaction, truly proved or accepted. Path coefficients are marked positive, theoretically it means that the influence of organizational commitment to work satisfaction is in the same direction. This indicates that lecturers who have high organizational commitment, then the work satisfaction will increase. Conversely, lecturers who have weak organizational commitment, so the work satisfaction will decrease.

The results of this study are in line with Sudiro's (2008) research; Westover et al., (2010); which stated that employees who have a high commitment to the organization then they can increase work satisfaction. However, 
this study differs from the study of Yiing and Zaman (2009) that found the opposite result in which organizational commitment has a significant negative effect on work satisfaction.

From the result of hypothesis testing $2 b$, path coefficient 0,564 ( $\mathrm{Sig}=0,000)$ from work satisfaction to organizational commitment of lecturers is significant with positive direction. The above results show that work satisfaction has a significant effect on organizational commitment of lecturers. It means that hypothesis $2 \mathrm{~b}$, which states work satisfaction has a positive effect on organizational commitment of lecturers, truly proved or accepted. Path coefficients are marked positive, theoretically it means that the effect of job satisfaction on organizational commitment is in the same direction. This indicates that the lecturers who work satisfaction is high, then the organizational commitment can increase. Conversely, lecturers whose work satisfaction is low, their organizational commitment may decrease further.

The results of this study are in line with studies from Lee and Mowday (1987), Gunz and Gunz (1994), Knoop (1995), Young et al. (1998), Martin \& O'Loughlin (1984), and carmeli et al. (2004) who found that job satisfaction has an effect on work commitment.

\subsubsection{The Effect of Performance to Work Satisfaction and the Vice Versa}

From the result of hypothesis 3a testing, path coefficient $0.382(\mathrm{Sig}=0.000)$ from performance to work satisfaction of lecturers is significant with positive direction. The above results show that the performance has a significant effect on the work satisfaction of lecturers. It means that hypothesis $3 \mathrm{a}$, which states the performance has a positive effect on the lecturers' work satisfaction, truly proved or accepted. Path coefficients are marked positive, theoretically it means that the influence of performance on lecturers' work satisfaction is in the same direction. This indicates that the lecturers who have good performance, then the work satisfaction can increase. Conversely, lecturers who have poor performance, then the work satisfaction can decrease.

The results of this study are in line with Lawler's and porter's (1967) research; Siegel and Bowen (1971); Stumpf and Hartman (1984); Karatepe and Tekinkus (2006); Zimmerman (2009) which stated that employees' performance will lead to work satisfaction.

From the result of hypothesis $3 \mathrm{~b}$ test, path coefficient $0.512(\mathrm{Sig}=0.000)$ from work satisfaction to lecturers' performance is significant with positive direction. The above results show that work satisfaction has a significant effect on lecturers' performance. It means that hypothesis $3 \mathrm{~b}$, which states that work satisfaction has a positive effect on the performance of lecturers, truly proved or accepted. Path coefficient marked positive, theoretically it means that the influence of work satisfaction on lecturers' performance is in the same direction. This indicates that the lecturers whose work satisfaction is high, the performance can increase. Conversely, lecturers whose work satisfaction is low, then their performance can decrease further.

The results were in line with the research of Chen et al. (2006); Lee et al. (1999); Melamed et al. (1995); Sekoran and Jauch (1978); Dickter et al. (1996); Sarmiento et al, (2007) that work satisfaction affects performance.

\subsection{The Implications of the Study}

The results of the study provide practical implications for private universities to pay attention to organizational commitment, performance and work satisfaction of lecturers. This is because the increased commitment, lecturers' performance and high lecturers' work satisfaction will help universities to be more advanced and developed. Therefore, it is important for private universities' leaders to pay attention to the factors that can increase commitment, performance and work satisfaction of lecturers such as appropriate motivation, lecturers' competence improvement through continuous training in development of learning method, and national and international scientific journal writing as well as stronger organizational commitment through the well application of policies, rules and academic atmosphere.

\subsection{The Limitation of the Study}

The results of this study still have some limitations in terms of:

1. The scope of this study does not cover all private universities in East Java but only 2 private religious universities.

2. In the process of implementing the distribution of questioners to the respondents, the researcher got difficulty to meet face-to-face and conduct in-depth interviews with the respondents. Because of that in several study programs, the researchers spread the questionnaire through the head of the study program and conducted insights into the head of the study program. Spreading of questioners through the head of this study program allows the bias perception of the respondent to the given questionnaire.

3. This study is a momentary study when it was distributed the questionnaire, so that it cannot be known continuously the change of performance and work satisfaction from lecturers, therefore this result cannot be generalized as the relation of three variables in long term.

\section{CONCLUSION}

Based on the purpose and result of the research, hence it can be compiled some conclusions as follows:

1. Organizational commitment has no significant effect on lecturers' performance. 
2. Performance has no significant effect on organizational commitment of lecturers.

3. Organizational commitment has a significant effect on the work satisfaction of lecturers.

4. Work satisfaction has a significant effect on organizational commitment of lecturers.

5. Performance has a significant effect on work satisfaction of lecturers.

6. Work satisfaction has a significant effect on lecturers' performance.

\section{REFERENCES}

Allen, N. J., and Meyer, J.P. 1990, The measurement and antecedents of affective, continuance, and normative commitment to organization. Journal of occupational psychology, 63, 1-18.

Bono, J.E, Judge, T.A., Thoresen, C.J. and Patton, G.K., 2001, The job satisfaction-job performance relationship: a qualitative and quantitative review. Psycological Bulletin, Vol. 127 No. 3, pp. 376-407

Burton, E., Gene, 2002, Jepang vs Amerika Serikat: Sebuah Perbandingan Lingkungan Perusahaan dan Karakteristik, Manusia Manajemen Sistem, 8 (2), 167-173.

Brayfield, A.H. and Crockett, W.H. 1955. Employee attitudes and employee performance. Psycological Bulletin, $52,396-424$.

Carmeli, A. and Freund, A. 2004." Work commitment, job satisfaction and job performance: An empirical investigation", International Journal of Organisation Theory and Behaviour, vol 7 No. 3, pp. 289-309

Chen, Z.X. and Francesco, C., 2003, The relationship between the three components of commitment and employee performance in china. Journal of Vacational Behaviour, Vol. 62 No. 3, pp. 490-510

Darwito, 2008, Analisis Pengaruh Gaya Kepemimpinan Terhadap Kepuasan Kerja Dan Komitmen Organisasi Untuk Meningkatkan Kinerja karyawan (Studi Pada RSUD Kota Semarang). http://eprints.undip.ac.id/16933/1/DARWITO.pdf

DeCotiis, T. and Summers, T., 1987, A path analysis of a model of the antecedents and consequences of organizational commitment. Human Relations, Vol. 40, pp. 445-70.

Gagnon, M.A. and Michael, J.H., 2004, Outcomes of perceived supervisor support for wood production employees. Forest Product Journal, Vol. 54 No. 12, pp. 172-7

Giddens, A., 2001, Runaway Word, London: Profile Books Ltd

Gunz, H.P. and Gunz S.P., 1994, Profesional/organizational commitment and job satisfaction for employed lawyers. Human Relations, 47, pp. 801-817

Herzberg, F., Mausner, B., Peterson R.O. and Capwell, D.F., 1957, Job Attitude: Review of Research and Opinion, Pittsburgh PA, Psychological service of Pittsburgh.

Ivancevich, John M., 1999. Organizational behavior and Management. Fifth edition.New York: Mc Graw-Hill.

Jaramillo F., J.P. Mulki, and G.W. Marshall, 2005, A Meta-analysis of the relationship between organizational commitment and salesperson job performance: 25 years of research. Journal of Business Research 58, pp.705714

Joyce, W. and Slocum, J.W., 1984, Collective climate: agreement as a basis for defining aggregate climates in organizations. Academy of Management Journal, Vol. 27 No. 4, pp. 721-42

Joyce, W. and Slocum, J.W. and Glinow, M.A., 1982, Person-situation interaction: competing models of fit. Journal of Occupational Behaviour, Vol. 3 No. 4, pp. 265-80.

Judge, T.A., Thoresen, C.J., Bono, J.E and Patton, G.K., 2001, The job satisfaction-job performance relationship: a qualitative and quantitative review. Psycological Bulletin, Vol. 127 No. 3, pp. 376-407

Karatepe M.O. and Tekinkus M., 2006, The effects of work family conflict, emotional exhaustion, and intrinsic motivation on job outcomes of front line employees. International Journal of Bank Marketing, Vol. 24 no. 3 , pp. 173-193.

Knoop, R., 1995, Relationship among job involvement, job satisfaction and organizational commitment for nurses. The Journal of Psychology, 129, pp. 643-649.

Laffaldano, M.T. \& Muchinsky, P.M., 1985, Job Satisfaction and Job Performance: A Meta-analysis, Psychological Bulletin, pp. 251-273

Lawler, E.E. and Porter, L.W., 1967, The effect of performance on job satisfaction, Industrial Relations, October 1967 , pp. $20-8$

Lee, T.W. \& Mowday, R.T. 1987. Voluntarily leaving an organization: An empirical investigation of Steers and Mowday's of turnover. Academy Management Journal. 721-743

Locke, E.A., 1970, Job Satisfaction and Job Performance: A Theoritical Analysis, Organizational Behaviour and Human Performance, pp. 484-500

Martin, T.N. and M.S. O’Laughlin, 1984, Predictors of organizational commitment: The study of part-time army reservists. Journal of vocational Behaviour, Vol. 25 No. 3, pp. 270-283

Mathieu, J.E., \& Zajac, D.M. 1990. A review and meta-analysis of the antecedents, correlates, and cobsequences of organizational commitment. Psychology Bulletin, 108: 171-194

Meyer, J.P. and N.J. Allen, 1997, Commitment in the workplace: Theory, Research, and Application. Thousand 
Oaks, CA: Sage Publication, Inc

Michael, J.H., Evans, D.D., Jansen, K.J. and Haight, J.M., 2005, Management commitment to safety as organizational support: relationships with non-safety outcomes in wood manufacturing employees. Journal of Safety Research, Vol. 36 No. 2, pp. 171-9.

Miller, R.I., 1980, Appraising institutional performance, Improving Academic Management, USA: John Wiley and Sons

Orpen, C., 1986, The effect of job performance on the relationship between job satisfaction and turnover. Journal of social psychology, Vol. 126 No. 2, pp. 277-8

Petty, M.M., McGee, G.W., \& Cavender J.W. 1984. A Meta-analysis of the relationships between individual job satisfaction and individual performance. Academy of Management review, 712-721

Porter, L.W. and Lawler, E.E., 1968, Managerial Attitudes and Performance, Dorsey Press, Homewood, IL

Roethlisberger, F.J. and Dickson, W.J. 1939. Management and the Worker, Harvard University Press, Cambridge, MA

Sallis, E., 2002, Total Quality Management in Education, London: kogan Page Limited.

Schwab, D.P. and Cummings, L.L. 1970. Theories of Performance and Satisfaction: A Review. Industrial Relations, 9, 408-430.

Siegel, J.P. and Bowen, D., 1971, Satisfaction and performance: causal relationships and moderating effects. Journal of Vocational Behavior, Vol. 1, pp. 263-9

Stumpf, S.A. and Hartman, K., 1984, Individual exploration to organizational commitment or withdral. Academy of Management Journal, Vol. 27, pp. 308-29

Sudiro Achmad, 2008, Pengaruh Timbal Balik Anatara Kepuasan Kerja dengan Kepuasan Keluarga dan Komitmen Kerja serta Dampaknya terhadap Prestasi Kerja dan Karier Dosen, Jurnal Manajemen dan Kewirausahaan, Vol. 10 No.1, hal. 38-49, Universitas Kristen Petra Surabaya.

Vroom, V.H., 1964, Work and Motivation. Wiley, New York, NY.

Westover H. Jonathan, A.R. Westover, and A.L. Westover, 2010, Enhancing long-term worker productivity and performance: The connection of key work domains to job satisfaction and organizational commitment. International Journal of Productivity and Performance Management, Volume 59 Iss: 4, pp 372-387

Wiener, Y. \& Vardi, Y. 1980. Relationships between job organization and career commitment and work outcomesan integrative approach. Organizational Behavior and Human Performance, pp 81-96.

Yiing H.Lee. and K. Zaman Bin Ahmad, 2009, The moderating effects of organizational culture on the relationships between leadership behavior and organizational commitment and between organizational commitment and job satisfaction and performance. Leadership \& Organization Development Journal, vol. 30 No. 1 , pp. 53-86.

Young, B.S., S. Worchel, and D.J. Woechr, 1998, Organizational commitment among public service employee. Public Personal Management, pp. 339-348

Zimmerman D. Ryan and T.C. Darnold, 2009, The impact of job performance on employee turnover intentions and the voluntary turnover process. A meta analysis and path model. Personal review, Vol 38 no 2, pp. 142158. 